\title{
Diagnosis Pertumbuhan Ekonomi dan Output Potensial Indonesia
}

\section{Asep Nurwanda*, Bakhtiar Rifai ${ }^{\alpha}$}

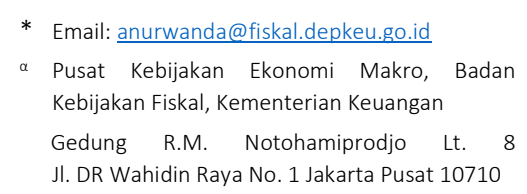

* Email: anurwanda@fiskal.depkeu.go.id

a Pusat Kebijakan Ekonomi Makro, Badan Kebijakan Fiskal, Kementerian Keuangan Gedung R.M. Notohamiprodjo Lt. 8 JI. DR Wahidin Raya No. 1 Jakarta Pusat 10710

Riwayat artikel:

- Diterima 26 Juni 2018

- Direvisi 10 Desember 2018

- Disetujui 11 Desember 2018

- Tersedia online 17 Desember 2018

Kata kunci: pertumbuhan ekonomi; output potensial; output gap; fungsi produksi

JEL Classification: D24, 040

DOI : 10.31685/kek.v2i3.385

\begin{abstract}
One of the tools to measure economic condition is the output gap analysis, which is the difference between actual and potential output. The results of this analysis illustrate the business cycle of an economy. It is essential as a basis for the macroeconomic and policy framework. This paper explains the estimation of Indonesia's potential output and output gap based on three approaches, namely Hodrick-Prescott (HP) Filter, Band-Pass (BP) Filter, and Production Function (Growth Accounting) Approach. Those three methods consistently show that Indonesia's economic condition in 2017 is only slightly below its potential level. Moreover, by applying the 2018 and 2019 growth projection of 5.4 and 5.6 percent respectively, the Indonesian economy will surpass its potential level by 2019. This condition needs to be of concern in policy making process, both in the short and medium term. In the short run, it drives an inflationary pressure, hence policies to control inflation should be a government priority. In the medium-term, the effort to conduct structural reforms should continue to improve potential output level. These efforts could cover the factor of labor (by improving labor force participation), the factor of capital (through the sustainable investment), and the factor of productivity (by improving human capital and technology).
\end{abstract}

\section{Abstrak}

Salah satu alat pendekatan yang digunakan dalam melakukan diagnosis posisi perekonomian suatu negara adalah analisis output gap yang merupakan selisih antara output aktual dan potensial. Hasil analisis tersebut menggambarkan kondisi siklus bisnis suatu perekonomian. Hal ini berguna sebagai dasar pertimbangan dalam penyusunan kerangka kebijakan ekonomi. Bertolak dari hal tersebut, tulisan ini menjelaskan hasil estimasi output potensial dan output gap Indonesia berdasarkan tiga pendekatan, yakni Hodrick-Prescott (HP) Filter, Band-Pass (BP) Filter, dan Pendekatan Fungsi Produksi (Growth Accounting). Ketiga metode tersebut secara konsisten menunjukkan bahwa kondisi perekonomian Indonesia di tahun 2017 hanya sedikit di bawah level potensialnya. Selanjutnya dengan mengaplikasikan asumsi kinerja pertumbuhan tahun 2018 dan 2019 masing-masing sebesar 5,4 persen dan 5,6 persen, perekonomian Indonesia akan melampaui level potensialnya di tahun 2019. Kondisi tersebut perlu menjadi perhatian dalam pengambilan kebijakan, baik dalam jangka pendek maupun menengah. Dalam jangka pendek, output gap yang positif mendorong adanya tekanan inflasi (inflationary pressure) sehingga upaya pengendalian inflasi perlu menjadi prioritas pemerintah. Sementara itu dalam jangka menengah, upaya reformasi struktural harus terus 
dilakukan untuk meningkatkan output potensial, mencakup faktor tenaga kerja peningkatan partisipasi angkatan kerja, faktor kapital melalui investasi yang berkelanjutan, serta faktor produktivitas dengan peningkatan kualitas human capital dan penguasaan teknologi. 


\section{PENDAHULUAN}

Pertumbuhan ekonomi merupakan salah satu indikator kunci dalam mengukur perkembangan ekonomi suatu negara. Analisis terkait pertumbuhan ekonomi ini penting dilakukan sebagai dasar dalam memformulasikan arah kebijakan ekonomi makro serta target pembangunan nasional. Hal ini sejalan dengan upaya untuk menciptakan pertumbuhan ekonomi yang tinggi dan berkualitas melalui bauran kebijakan pemerintah baik dari sisi fiskal maupun moneter. Formulasi kebijakan ekonomi yang dilakukan harus dapat mempertimbangkan siklus bisnis (business cycles) yang terjadi dalam perekonomian agar kebijakan tersebut lebih tepat sasaran. Salah satu alat analisis yang sering digunakan dalam melakukan diagnosis posisi perekonomian dalam siklus bisnis adalah melalui pendekatan output gap.

Output gap secara sederhana dapat menggambarkan adanya kelebihan permintaan (excess demand) atau penggunaan kapasitas produksi yang rendah (idle resource) di dalam suatu perekonomian. Output gap merupakan deviasi antara output aktual (actual output) dengan output potensial (potential output) sebagaimana diilustrasikan pada Gambar 1. Output aktual adalah nilai output perekonomian yang ditentukan oleh permintaan selama siklus bisnis yang di-proxy dengan nilai Produk Domestik Bruto (PDB). Sementara itu, output potensial dapat didefinisikan sebagai tingkat produksi optimal dimana input tenaga kerja dan modal digunakan pada tingkat kapasitas jangka panjang yang berkelanjutan, dengan tingkat pengangguran natural dan inflasi yang stabil. De Masi (1997) menyatakan bahwa output potensial merepresentasikan output maksimal yang dapat dihasilkan dalam suatu perekonomian tanpa menyebabkan tekanan inflasi.

\section{GAMBAR I: Output Aktual, Output Potensial, dan Output Gap}

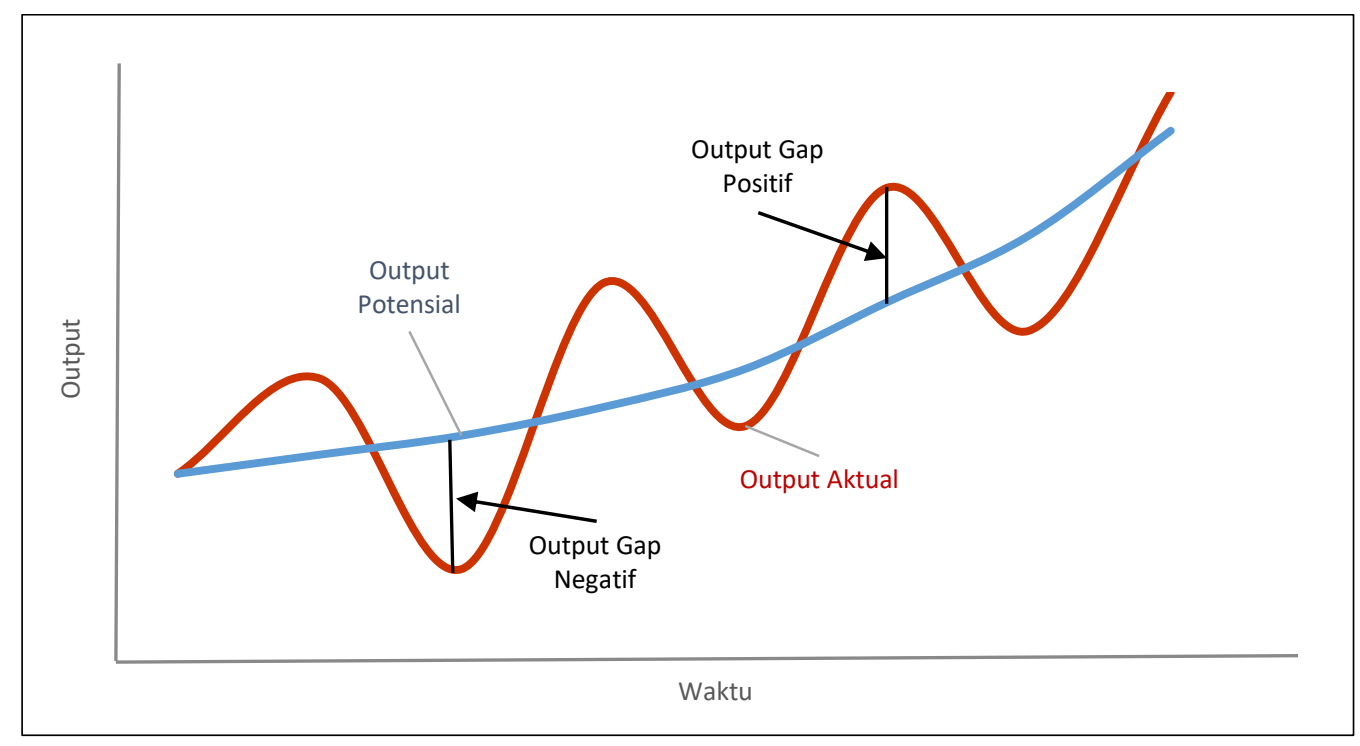

Output potensial dan output gap merupakan input penting dalam kerangka kebijakan ekonomi makro. Output potensial digunakan sebagai ukuran produksi atau kapasitas suatu perekonomian pada sisi penawaran yang dinilai berdasarkan stok modal, penggunaan tenaga kerja, dan teknologi yang tersedia. Dalam jangka panjang, output potensial ditentukan oleh utilisasi faktor-faktor produksi yang tersedia secara efisien untuk tingkat produktivitas tertentu. Namun dalam jangka pendek permintaan agregat bisa mendorong tingkat produksi melebihi output potensial jangka panjang. Kondisi ini menimbulkan tekanan dalam bentuk kelebihan permintaan di pasar barang dan tenaga kerja yang pada akhirnya menyebabkan kenaikan inflasi.

Perhitungan output gap dapat menentukan posisi siklus bisnis atau kondisi perekonomian sebagai dasar dalam menentukan kebijakan baik fiskal maupun moneter. Apabila output aktual lebih tinggi dari output potensial (output gap positif), hal ini mengindikasikan perekonomian dalam kondisi boom/ekspansi dan mendorong adanya tekanan inflasi sehingga membutuhkan respon kebijakan fiskal yang kontraktif, seperti mengurangi belanja, meningkatkan pajak, serta kebijakan moneter yang ketat, seperti peningkatan suku bunga. Sebaliknya, output aktual yang lebih rendah dibandingkan dengan output potensial (output gap negatif) mencerminkan penggunaan 
kapasitas produksi yang tidak optimal sehingga menyebabkan peningkatan pengangguran dan deflasi (perekonomian dalam masa resesi). Pada Kondisi ini, dibutuhkan respon kebijakan baik fiskal maupun moneter yang ekspansif untuk dapat meningkatkan atau menciptakan permintaan.

Diagnosis yang tepat terhadap kondisi pertumbuhan ekonomi dan output potensial dapat menjadi dasar dalam mengukur dan memperkirakan perekonomian jangka menengah dan panjang. Oleh sebab itu, tulisan ini disusun untuk melakukan diagnosis pertumbuhan ekonomi Indonesia dan posisinya dalam siklus bisnis dengan menerapkan beberapa pendekatan analisis serta memberikan rekomendasi kebijakan untuk mencapai pertumbuhan ekonomi yang lebih sustainable. Sebelumnya, Nasution dan Hendranata (2014) juga telah melakukan penelitian dengan menggunakan metode estimasi output potensial yang relatif sama dengan data tahunan hingga 2013. Namun demikian, tulisan ini menggunakan data terkini (lebih up date) dan dengan periode triwulanan (high frequency) sehingga dapat memperkaya analisis dan menggambarkan dinamika yang lebih lengkap.

Tulisan ini dibagi menjadi lima bagian utama, yaitu: (1) Pendahuluan, bagian ini berisi latar belakang, tujuan, dan kontribusi penelitian; (2) Tinjauan pustaka, akan menjelaskan tentang teori dan review literatur terkait dengan pertumbuhan ekonomi dan output potensial; (3) Metodologi penelitian, bagian ini menjelaskan tentang data dan alat analisis yang digunakan untuk mengestimasi output potensial dan output gap; (4) Analisis, bagian ini berisi tentang penjelasan hasil perhitungan dari output potensial dan output gap Indonesia, serta analisis dekomposisi dari pendekatan fungsi produksi; (5) Kesimpulan dan Rekomendasi, bagian akhir ini akan berisi masukan dan saran untuk pembuat kebijakan berdasarkan hasil perhitungan output potensial dan output gap ini.

\section{TINJAUAN PUSTAKA}

\subsection{Teori Pertumbuhan Ekonomi: Model Pertumbuhan Solow}

Model pertumbuhan Solow menunjukkan bagaimana pertumbuhan persediaan modal, pertumbuhan angkatan kerja, dan kemajuan teknologi berinteraksi dalam perekonomian, serta bagaimana pengaruhnya terhadap output barang dan jasa suatu negara secara keseluruhan (Mankiw, 2010). Model pertumbuhan Solow mengasumsikan bahwa pertumbuhan ekonomi dipengaruhi oleh perubahan faktor produksi modal fisik (tabungan dan investasi) dan tenaga kerja (pertumbuhan populasi), sementara teknologi yang menggambarkan tingkat efisiensi merupakan variabel eksogen dan dianggap sebagai residual. Tingkat teknologi ini memberikan gambaran interaksi antara kedua faktor input yaitu modal dan tenaga kerja. Teknologi dalam hal ini merupakan pengetahuan (knowledge) tentang bagaimana melakukan atau memproduksi sesuatu dengan cara yang paling efisien. Pertumbuhan ekonomi dalam jangka pendek dapat dicapai dengan adanya peningkatan efisiensi pada penggunaan input kapital dan tenaga kerja. Sementara pertumbuhan ekonomi dalam jangka panjang dipengaruhi oleh adanya akumulasi kapital yang menjadi kunci utama untuk mencapai jalur pertumbuhan optimal dan stabil.

Dalam model pertumbuhan Solow, input tenaga kerja dan modal memakai asumsi skala yang terus berkurang (diminishing returns) jika keduanya dianalisis secara terpisah, sedangkan jika keduanya dianalisis secara bersamaan memakai asumsi skala hasil tetap (constant returns to scale) (Todaro dan Smith, 2006). Model pertumbuhan Solow dapat ditulis:

$$
Y=A K^{\propto} L^{1-\propto}
$$

dimana:

Y : Output barang dan jasa (Produk Domestik Bruto/PDB)

A : tingkat kemajuan teknologi/Total Factor Productivity (TFP)

$\mathrm{K}$ : stok modal fisik/kapital

L : tenaga kerja

$\alpha$ : elastisitas output terhadap modal/kapital (persentase kenaikan PDB yang bersumber dari 1 persen penambahan modal fisik)

Model pertumbuhan Solow menekankan pentingnya peranan investasi dalam proses akumulasi modal fisik. Laju pertumbuhan ekonomi akan ditentukan oleh tingkat akumulasi kapital per tenaga kerja. Berdasarkan model 
ini, negara yang memiliki akumulasi kapital lebih baik akan tumbuh lebih tinggi. Dalam bentuk pertumbuhan, model Solow tersebut dapat dituliskan sebagai berikut:

$$
\frac{\Delta \mathrm{Y}}{Y}=\frac{\Delta \mathrm{A}}{A}+a \frac{\Delta \mathrm{K}}{K}+(1-a) \frac{\Delta \mathrm{L}}{L}
$$

dimana:

$\frac{\Delta \mathrm{A}}{A} \quad$ : pertumbuhan total factor productivity

a : Kontribusi modal fisik/kapital terhadap GDP

$1-a \quad$ : Kontribusi tenaga kerja terhadap GDP

Kemajuan teknologi dalam model Solow ditetapkan sebagai komponen residu (Solow Residual) untuk menjelaskan pertumbuhan ekonomi dalam jangka panjang. Tinggi rendahnya pertumbuhan teknologi ini oleh Solow maupun para ahli teori lainnya diasumsikan bersifat eksogen atau tidak dipengaruhi faktor-faktor lain.

\subsection{Studi Literatur}

Output potensial dan output gap menjadi salah satu metode yang umum digunakan dalam rangka mengukur posisi siklus bisnis dalam suatu perekonomian. Posisi siklus bisnis dimaksud dapat memberikan gambaran terkait dengan arah kebijakan baik fiskal maupun moneter yang bersifat counter cyclical. Berbagai studi banyak dilakukan dalam rangka melakukan estimasi output potensial dan output gap. De Masi (1997) melakukan review terkait teknik estimasi output potensial baik secara teori maupun praktik yang dilakukan oleh International Monetary Fund (IMF) dalam rangka memberikan rekomendasi kebijakan untuk negara anggotanya. Tulisan tersebut membahas tentang metodologi dan hasil temuan terkait output potensial untuk kategori negara industri, negara berkembang, dan negara yang berada dalam masa transisi. Sebagian besar metode yang digunakan dalam tulisan tersebut adalah dengan menggunakan pendekatan fungsi produksi, dimana metode tersebut memberikan kelebihan dalam melakukan identifikasi faktor yang berkontribusi terhadap perubahan output potensial. Namun demikian, beberapa metode lain seperti teknik univariate detrending dan HP-Filter juga tetap digunakan tergantung dengan karakteristik dan ketersediaan data dari masing-masing negara.

Sigit (2004) melakukan penelitian terhadap TFP dan pertumbuhan ekonomi di Indonesia periode 1980-2000 yang menjadi bagian dari hasil survei Asian Productivity Organization (APO) dengan menggunakan pendekatan fungsi produksi dan growth accounting. Temuan dari penelitian tersebut diantaranya: (i) pertumbuhan ekonomi di Indonesia didorong oleh peningkatan akumulasi modal; (ii) kontribusi tenaga kerja terhadap pertumbuhan GDP relatif kecil diakibatkan tingkat pertumbuhan lapangan kerja yang rendah sekitar 2-2,5 persen per tahun dan banyaknya tenaga kerja yang bekerja pada sektor informal; (iii) peningkatan produktivitas relatif rendah dalam kisaran 1 persen bahkan dalam periode tertentu tumbuh negatif. Pertumbuhan TFP secara signifikan dipengaruhi oleh tingkat pendidikan pekerja dan besarnya kontribusi dari produktivitas modal.

Anand et al (2014) melakukan penelitian terkait output potensial pada beberapa negara berkembang Asia seperti China, India, dan 5 negara ASEAN (Indonesia, Malaysia, Filipina, Thailand, dan Vietnam) dalam periode waktu 1993-2013 dengan menggunakan pendekatan fungsi produksi. Beberapa kesimpulan dari penelitian ini antara lain: (i) China dan India mengalami pelemahan pertumbuhan output potensial, terutama akibat penurunan TFP; (ii) tren pertumbuhan untuk 5 negara ASEAN relatif stabil dan bahkan cenderung sedikit meningkat, kecuali untuk Vietnam; (iii) dalam jangka panjang, faktor demografi akan menjadi faktor pendorong untuk India dan beberapa negara ASEAN dibandingkan China yang mengalami penurunan angkatan kerja, sehingga untuk meningkatkan atau mempertahankan pertumbuhan potensial mambutuhkan reformasi struktural yang lebih luas.

Lebih lanjut, Nasution dan Hendranata (2014) melakukan perhitungan output gap Indonesia dengan menggunakan beberapa pendekatan diantaranya HP Filter, BandPass Filter, ARIMA+HP Filter, fungsi produksi, dan SVAR. Hasil penelitian ini menemukan bahwa pada tahun 2014-2015 PDB aktual Indonesia lebih rendah dibandingkan PDB potensialnya, sehingga kebijakan yang seharusnya dilakukan Pemerintah dan Bank Sentral adalah kebijakan yang bersifat longgar. 


\section{METODE PENELITIAN}

\subsection{Metodologi Estimasi Output Potensial}

Terdapat dua metode pendekatan yang digunakan secara umum dalam mengestimasi output potensial dan output gap, yaitu metode univariate dan quasi-theoretical. Metode univariate pada dasarnya adalah metode statistik murni yang tidak mengikutsertakan hubungan antar variabel makroekonomi. Metode ini dilakukan dengan cara mendekomposisi variabel time series menjadi komponen permanen dan siklus. Termasuk dalam kategori ini adalah Hodrick-Prescott Filter (HP Filter), Band-Pass Filter (BP Filter), Baxter King, dan Beveridge-Nelson. Sementara itu, pendekatan quasi-theoritical adalah pendekatan dengan membangun model yang didasarkan pada teori ekonomi dan hubungan antar variabel makroekonomi. Pendekatan fungsi produksi termasuk dalam kategori ini. Dalam tulisan ini, tiga pendekatan digunakan untuk mengestimasi output potensial, yakni dengan teknik time series filtering yang mencakup HP Filter dan BP Filter, serta pendekatan quasi-theoritical.

Adapun penjelasan penggunaan tiga pendekatan analisis dalam tulisan ini, adalah sebagai berikut.

a. Metode statistik murni berdasarkan teknik time series filtering

Pendekatan ini mengestimasi tren atau kecenderungan dari data output aktual, biasanya diturunkan melalui dekomposisi statistik atau dengan cara memisahkan (filtering) data output aktual menjadi komponen cyclical dan komponen tren. Metode yang umum digunakan antara lain Hodrick-Prescott filter dan Band-Pass Filter. Keuntungan dari metode ini adalah relatif sederhana dan transparan. Di sisi lain, karena pendekatan ini menggunakan perhitungan statistik murni, filter tersebut mengukur tren pertumbuhan tanpa pemetaan yang kuat terhadap teori ekonomi dan mengabaikan hubungan antar variabel ekonomi, sehingga menjadi sulit untuk menjelaskan dinamika yang dihasilkan sesuai dengan teori ekonomi.

1) Hodrick-Prescott (HP) Filter

HP Filter adalah teknik penghalusan data (smoothing) yang tergolong sederhana dan menjadi metode paling umum digunakan dalam mengestimasi output potensial. Metode ini meminimisasi perbedaan antara output aktual dan output potensial dan membatasi tingkat perubahan output potensial untuk seluruh sampel observasi (T). Persamaan HP Filter dapat dituliskan sebagai berikut:

$$
\operatorname{Min} \sum_{t=1}^{T}\left(y_{t}-y_{t}^{*}\right)^{2}+\lambda \sum_{t=2}^{T=1}\left[\left(y_{t+1}^{*}-y_{t}^{*}\right)-\left(y_{t}^{*}-y_{t-1}^{*}\right)\right]^{2}
$$

dimana y adalah output aktual (PDB riil), $\mathrm{y}^{*}$ adalah output potensial, $\lambda$ adalah faktor pembobot yang menentukan degree of smoothness dari tren. Semakin kecil nilai $\lambda$, akan menyebabkan output potensial cenderung mendekati nilai output aktualnya. Sebaliknya jika $\lambda$ semakin besar, maka output potensial yang dihasilkan akan menjadi lebih halus dan menjauhi data aktualnya.

Berdasarkan hal tersebut, estimasi output potensial dengan menggunakan HP Filter sangat tergantung pada pemilihan nilai $\lambda$. Praktik standar yang biasa digunakan untuk menentukan besaran $\lambda$ adalah dengan menggunakan persamaan $\lambda=100 q^{2}$, dimana $\mathrm{q}$ adalah periodisitas data, sehingga dengan menggunakan rumus tersebut nilai $\lambda$ adalah 100 untuk data tahunan, 1600 untuk data kuartalan, dan 14400 untuk data bulanan.

2) Band-Pass (BP) Filter

Band-Pass Filter adalah filter yang bersifat linear yang mengambil rata-rata bergerak tertimbang di kedua sisi data, dimana siklusnya berada dalam sebuah rentang (band) pada kisaran batas bawah dan batas atas yang ditentukan, sementara siklus yang lain dikeluarkan. Dengan kata lain, BP Filter memisahkan komponen dari data time series yang terletak pada rentang frekuensi tertentu (Christiano dan Fitzgerald, 1999).

BP Filter didasarkan pada ide bahwa siklus bisnis dapat ditentukan sebagai fluktuasi dari frekuensi tertentu. Fluktuasi dengan frekuensi yang lebih tinggi dianggap sebagai faktor musiman, sementara 
frekuensi yang lebih rendah diasosiasikan sebagai tren. Di sisi lain, komponen frekuensi medium dari data dijelaskan sebagai komponen cyclical atau siklus bisnis dan menjadi fokus dari BP Filter ini.

Kisaran durasi harus ditentukan berdasarkan pengetahuan mengenai kisaran panjang siklus bisnis dari suatu negara, dimana informasi ini seringkali belum tersedia atau berbeda untuk berbagai negara. Praktik standar yang umumnya digunakan mengasumsikan siklus bisnis adalah dalam rentang siklus bawah 6 kuartal (1,5 tahun) dan siklus atas 32 kuartal (8 tahun).

BP Filter menggunakan teori dekomposisi untuk memisahkan data menjadi komponen frekuensi yang berbeda:

$$
X_{t}=y_{t}+\tilde{X}_{t}
$$

Dimana $X_{t}$ adalah output aktual; $y_{t}$ adalah output gap atau komponen dari $X_{t}$ dengan variasi periode antara siklus bawah dan siklus atas (sesuai konsensus untuk data kuartalan adalah 6 dan 32), dan; $\tilde{X}_{t}$ adalah output potensial.

b. Pendekatan Fungsi Produksi dan Growth Accounting

Pendekatan ini menghubungkan antara output potensial dengan faktor input. Solow dalam teori pertumbuhannya mengasumsikan bahwa output (pertumbuhan ekonomi) ditentukan oleh input modal (capital) dan tenaga kerja (labor). Kedua input tersebut juga saling berinteraksi pada tingkat teknologi tertentu. Teknologi dalam hal ini merupakan pengetahuan (knowledge) tentang bagaimana melakukan atau memproduksi sesuatu dengan cara yang paling efisien. Salah satu indikator tingkat kemajuan teknologi/produktivitas suatu negara ini dapat dilihat dari nilai Total Factor Productivity (TFP). TFP mencerminkan nilai efisiensi dari masing-masing komponen faktor produksi. Semakin tinggi TFP maka semakin efisien penggunaan komponen-komponen faktor produksi dalam menghasilkan output. Model pertumbuhan Solow dapat ditulis:

$$
Y_{t}=A_{t} \cdot K_{t}^{\propto} \cdot L_{t}^{1-\propto}
$$

Dimana Y adalah output barang dan jasa; A adalah TFP; K adalah modal/kapital; L adalah tenaga kerja, dan; $\propto$ adalah kontribusi kapital terhadap output.

Peningkatan efisiensi produksi menyebabkan pergeseran menuju fungsi produksi (dari titik A ke B). Sementara, kemajuan atau perubahan teknologi menyebabkan peningkatan output yang dihasilkan, dengan menggeser kurva fungsi produksi dari titik B ke C). Lebih lanjut, peningkatan output dari titik C ke D diakibatkan oleh peningkatan input dari $\mathrm{X}_{1}$ ke $\mathrm{X}_{2}$.

\section{GAMBAR 2: Fungsi Produksi}

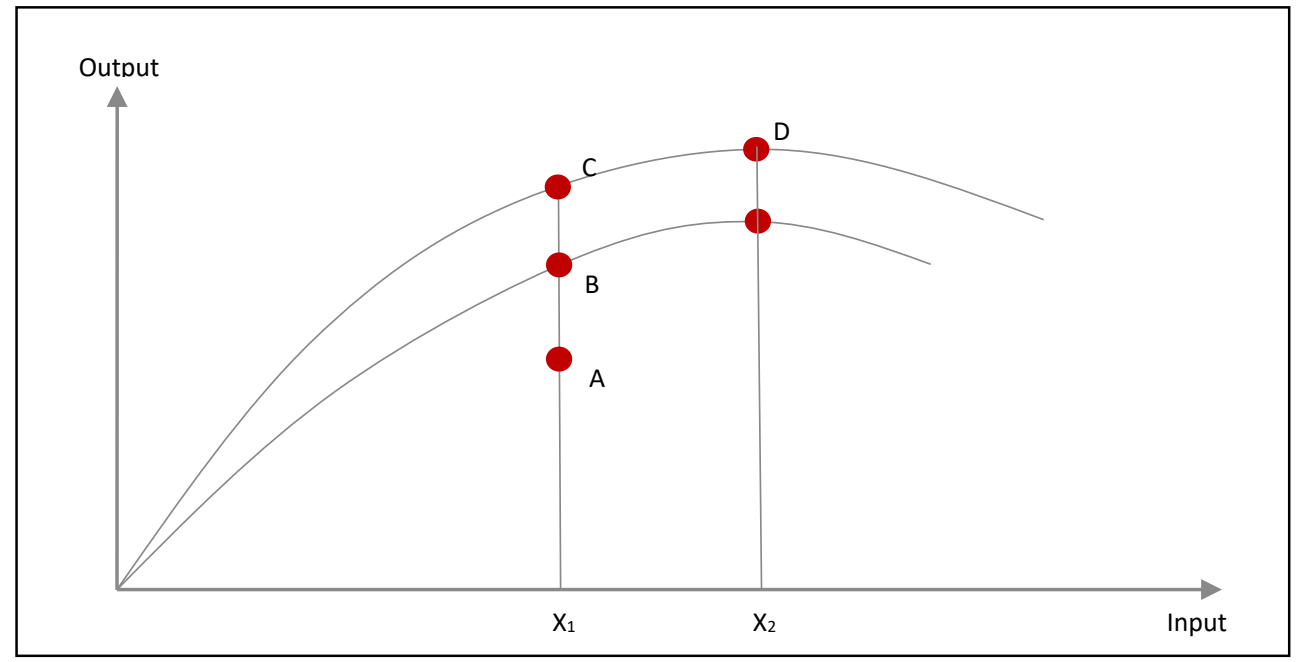


TFP tidak dapat diamati secara langsung dan biasanya diturunkan sebagai residual Solow dari kerangka growth accounting sesuai persamaan sebagai berikut:

$$
\dot{Y}=\dot{A}+\alpha \dot{K}+\beta \dot{L}
$$

Tanda dot (.) mengindikasikan pertumbuhan dari masing-masing komponen. Notasi dari $\dot{Y}$ adalah pertumbuhan dari output; $\dot{K}$ adalah pertumbuhan dari kapital; $\dot{L}$ adalah pertumbuhan dari tenaga kerja; $\dot{A}$ adalah pertumbuhan dari kemajuan teknologi; $\alpha$ adalah elastisitas kapital terhadap output, dan $\beta$ adalah elastisitas tenaga kerja terhadap output. Dalam melakukan estimasi output potensial dengan pendekatan fungsi produksi ini, Tahapan yang perlu dilakukan adalah sebagai berikut:

1) Estimasi nilai awal stok kapital (initial capital stock) dengan menggunakan pendekatan accelerator model, sebagai berikut:

Dimana:

$$
\chi_{t}=\frac{I_{t}}{\left(g_{t}+\delta_{t}\right) Y_{t}}
$$

$\chi_{t}=$ nilai awal stok kapital pada periode $\mathrm{t}$

$I_{t}=$ tambahan investasi baru/pembentukan modal tetap bruto pada periode $\mathrm{t}$

$g_{t}=$ tingkat pertumbuhan GDP pada periode $t$

$\delta_{t}=$ nilai depresiasi (penyusutan) pada periode $\mathrm{t}$

$Y_{t}=$ PDB/output pada periode $\mathrm{t}$

2) Estimasi stok kapital dengan menggunakan perpetual inventory method

Stok kapital dapat dihitung dengan menggunakan rumus sebagai berikut:

$$
K_{t}=(1-\delta) K_{t-1}+I_{t}
$$

Dimana:

$K_{t} \quad=$ stok kapital pada periode $\mathrm{t}$

$K_{t-1} \quad=$ stok kapital pada periode $t-1$

$\delta \quad=$ nilai penyusutan (depresiasi) pada periode $\mathrm{t}$

$I_{t} \quad=$ tambahan investasi baru pada periode $t$

3) Melakukan smoothing terhadap komponen fungsi produksi (tenaga kerja dan TFP)

Tujuan dari proses smoothing adalah untuk mendekomposisi sebuah series (seperti TFP dan jumlah tenaga kerja) menjadi komponen cyclical dan tren. Hasil dari komponen tren dapat digunakan untuk menghitung output potensial sebagai komponen input pada fungsi produksi. Dalam tulisan ini, proses smoothing dilakukan dengan menggunakan HP Filter.

4) Menghitung Total Factor Productivity (TFP)

TFP adalah porsi dari output $\left(\mathrm{Y}_{\mathrm{t}}\right)$ yang tidak dapat dijelaskan oleh komposisi/jumlah input yang digunakan dalam proses produksi. Berdasarkan fungsi produki, TFP secara matematis dapat dituliskan sebagai berikut:

$$
A_{t}=\frac{Y_{t}}{K_{t}^{\alpha} \cdot L_{t}^{(1-\alpha)}}
$$

TFP merepresentasikan tingkat perkembangan teknologi dalam suatu perekonomian pada periode $t$ serta tingkat produktivitas efektif dari kombinasi input modal dan tenaga kerja. TFP merupakan bentuk residual dari fungsi produksi.

5) Menghitung output potensial dengan menggunakan fungsi produksi agregat

Setelah mendapatkan komponen potential capital $\left(K_{t}^{*}\right)$, potential labor $\left(L_{t}^{*}\right)$, dan potential TFP $\left(A_{t}^{*}\right)$. Selanjutnya angka tersebut dapat digunakan untuk menghitung output potensial $\left(Y_{t}^{*}\right)$ sebagai berikut:

$$
Y_{t}^{*}=A_{t}^{*} \cdot K_{t}^{* \propto} \cdot L_{t}^{* 1-\propto}
$$


Pendekatan fungsi produksi ini dibangun berdasarkan teori ekonomi dan mengikutsertakan variabel kunci ekonomi makro, sehingga model ini memiliki kelebihan yakni dapat menjelaskan dinamika dari hasil estimasi output potensial dan output gap berdasarkan teori ataupun penjelasan empiris. Pendekatan ini juga dapat mengidentifikasi faktor pendorong pertumbuhan di masa lampau dan memberikan tanda perubahan struktural dalam suatu tren pertumbuhan. Namun dikarenakan dalam menghitung level potensial dari komponen faktor produksi masih menggunakan teknik time series filtering, maka pendekatan ini juga memiliki kelemahan seperti pada teknik filtering.

Berdasarkan penjelasan terkait dengan metode yang digunakan dalam mengestimasi output potensial dan output gap, maka dapat disimpulkan kelebihan dan kekurangan dari masing-masing model pada tabel 1 sebagai berikut:

TABEL-1: Kelebihan dan Kekurangan Metode Estimasi Output Potensial

\begin{tabular}{|c|c|c|}
\hline Metode & Kelebihan & Kekurangan \\
\hline $\begin{array}{l}\text { Metode time } \\
\text { series / } \\
\text { statistik } \\
\text { filtering }\end{array}$ & $\begin{array}{l}\text { - Sederhana dan transparan } \\
\text { - Data "berbicara" } \\
\text { - Pendekatan yang cepat dan dapat } \\
\text { digunakan untuk pendekatan yang } \\
\text { lain }\end{array}$ & $\begin{array}{l}\text { - Tidak menggunakan landasan teori } \\
\text { yang kuat } \\
\text { - Permasalahan prediksi di titik akhir } \\
\text { (end point) } \\
\text { - Sensitif terhadap parameter } \\
\text { - Backward looking (aktual) }\end{array}$ \\
\hline $\begin{array}{l}\text { Fungsi } \\
\text { produksi dan } \\
\text { growth } \\
\text { accounting }\end{array}$ & $\begin{array}{l}\text { - Transparan dan fleksibel } \\
\text { - Dapat melakukan breakdown dan } \\
\text { perkiraan faktor pendorong } \\
\text { pertumbuhan di masa lalu } \\
\text { - Dasar untuk menentukan tren di masa } \\
\text { depan melalui skenario pertumbuhan } \\
\text { masing-masing komponen }\end{array}$ & $\begin{array}{l}\text { - Tidak ada hubungan langsung } \\
\text { antara tren output dan inflasi } \\
\text { - Bergantung pada parameter, misal } \\
\text { estimasi stok kapital (K) } \\
\text { - Faktor input yang di"smoothing", } \\
\text { sehingga memiliki kelemahan } \\
\text { seperti teknik filtering }\end{array}$ \\
\hline
\end{tabular}

Sumber: Presentasi Khatri dalam Workshop Estimating Indonesia's Potential Output, 2017.

Selanjutnya, hasil estimasi output potensial dari masing-masing pendekatan dimaksud dibandingkan dengan output aktual-nya guna mendapatkan output gap dengan formula perhitungan sebagai berikut:

$$
G A P_{t}^{*}=\left(\frac{Y_{t}-Y_{t}^{*}}{Y_{t}^{*}}\right) * 100
$$

Dimana

$G A P_{t}^{*} \quad=$ output gap pada periode $\mathrm{t}$

$Y_{t} \quad=$ level PDB/output aktual pada periode $t$

$Y_{t}^{*} \quad=$ level PDB /output potensial pada periode $\mathrm{t}$

\subsection{Data}

Metode pengumpulan data yang digunakan adalah melalui metode dokumentasi dengan mengumpulkan data dari laporan-laporan terseleksi yang relevan dengan topik permasalahan penelitian ini. Sementara itu, berdasarkan perolehan sumber data, penelitian ini menggunakan data sekunder yang diperoleh dari lembaga pengumpulan data yang dipublikasikan kepada masyarakat pengguna data.

Data yang digunakan dalam kajian ini menggunakan data time series berupa data triwulan periode waktu 1993 sampai dengan 2017. Sebagian besar data yang digunakan adalah berasal dari CEIC, Badan Pusat Statistik (BPS), Total Economic Database, dan Kementerian Keuangan. Adapun detail data yang digunakan dalam tulisan ini adalah sebagai berikut:

TABEL-2: Data dan Definisi Variabel untuk Estimasi Output Potensial

\begin{tabular}{llcc}
\hline \multicolumn{1}{c}{ Data dan Notasi } & \multicolumn{1}{c}{ Definisi } & Satuan & Sumber \\
\hline Produk Domestik & Jumlah nilai tambah yang dihasilkan oleh seluruh & Juta & BPS \\
Bruto Riil: Non & unit usaha dalam suatu negara tertentu, atau & Rupiah \\
Seasonal Adjusted & merupakan jumlah nilai barang dan jasa akhir yang & \\
(Y NSA) & dihasilkan oleh seluruh unit ekonomi yang dihitung & \\
& menggunakan harga yang berlaku pada satu tahun & \\
& tertentu sebagai dasar (tahun 2010). & \\
\hline
\end{tabular}




\begin{tabular}{|c|c|c|c|}
\hline Data dan Notasi & Definisi & Satuan & Sumber \\
\hline $\begin{array}{l}\text { Produk Domestik } \\
\text { Bruto Riil: Seasonal } \\
\text { Adjusted (Y SA) }\end{array}$ & $\begin{array}{l}\text { Data PDB yang efek/pola musimannya telah } \\
\text { dihilangkan dengan menggunakan metode statistik } \\
\text { tertentu, dalam tulisan ini dengan menggunakan } \\
\text { ARIMA X-12. }\end{array}$ & $\begin{array}{l}\text { Juta } \\
\text { Rupiah }\end{array}$ & $\begin{array}{l}\text { BPS dan } \\
\text { CEIC, } \\
\text { diolah }\end{array}$ \\
\hline $\begin{array}{l}\text { Pembentukan Modal } \\
\text { Tetap Bruto Riil (I) }\end{array}$ & $\begin{array}{l}\text { Penambahan (serta pengurangan) barang modal } \\
\text { (investasi) pada suatu periode tertentu yang } \\
\text { meliputi komponen bangunan, mesin dan } \\
\text { perlengkapan, kendaraan, peralatan lainnya, } \\
\text { cultivated biological resource (CBR), dan produk } \\
\text { kekayaan intelektual. }\end{array}$ & $\begin{array}{l}\text { Juta } \\
\text { Rupiah }\end{array}$ & BPS \\
\hline $\begin{array}{l}\text { Tingkat Depresiasi } \\
(\delta)\end{array}$ & $\begin{array}{l}\text { Persentase rata-rata tertimbang (weighted average) } \\
\text { tingkat depresiasi dari masing-masing komponen } \\
\text { pembentuk PMTB. Tingkat penyusutan barang } \\
\text { modal (aktiva tetap) yang dihitung dengan } \\
\text { menggunakan metode garis lurus (straight line) } \\
\text { untuk masing-masing jenis aktiva tetap, yakni } \\
\text { bangunan } 20 \text { tahun, mesin dan perlengkapan } 5 \\
\text { tahun, kendaraan } 5 \text { tahun, peralatan lainnya } 5 \\
\text { tahun, CBR } 10 \text { tahun, serta produk kekayaan } \\
\text { intelektual } 20 \text { tahun. }\end{array}$ & Persen & BPS \\
\hline $\begin{array}{l}\text { Jumlah Tenaga Kerja } \\
\text { (L) }\end{array}$ & $\begin{array}{l}\text { Penduduk usia kerja (15 tahun dan lebih) yang } \\
\text { bekerja. Data yang dipublikasikan adalah data } \\
\text { semesteran (Februari dan Agustus), Untuk } \\
\text { mendapatkan data kuartalan menggunakan metode } \\
\text { interpolasi linier. }\end{array}$ & $\begin{array}{c}\text { Juta } \\
\text { Orang }\end{array}$ & BPS \\
\hline $\begin{array}{l}\text { Labor Income Share } \\
(1-\propto)\end{array}$ & $\begin{array}{l}\text { Elastisitas output terhadap tenaga kerja (persentase } \\
\text { kenaikan PDB yang bersumber dari } 1 \text { persen } \\
\text { penambahan tenaga kerja). }\end{array}$ & Persen & $\begin{array}{l}\text { Total } \\
\text { Economic } \\
\text { Database }\end{array}$ \\
\hline Inflasi $(\pi)$ & $\begin{array}{l}\text { Diukur dengan menggunakan Indeks Harga } \\
\text { Konsumen (IHK) yang menghitung rata-rata } \\
\text { perubahan harga dari suatu paket barang dan jasa } \\
\text { yang dikonsumsi oleh rumah tangga dalam kurun } \\
\text { waktu tertentu. Perubahan IHK dari waktu ke waktu } \\
\text { menggambarkan tingkat kenaikan (inflasi) atau } \\
\text { tingkat penurunan (deflasi) dari barang dan jasa. }\end{array}$ & Persen & BPS \\
\hline
\end{tabular}

Selain data historis (realisasi), tulisan ini juga menggunakan data asumsi pertumbuhan ekonomi, pertumbuhan investasi, dan jumlah tenaga kerja di tahun 2018 dan 2019 yang diproyeksi oleh Kementerian Keuangan. Data dimaksud digunakan untuk mengestimasi perkembangan output potensial dan output gap serta menunjukkan posisi perekonomian Indonesia dalam siklus bisnis di tahun 2018 dan 2019.

\section{HASIL ANALISIS DAN PEMBAHASAN}

\subsection{Hasil Estimasi Output Potensial}

Secara umum, hasil estimasi output potensial dan output gap dengan menggunakan metode HP Filter, Band Pass Filter, dan fungsi produksi menunjukkan hasil, pola, dan arah pergerakan yang cukup konsisten meskipun dengan besaran (magnitude) yang berbeda. Hal ini terutama terlihat pada hasil estimasi laju pertumbuhan potensial tahun 1994 s.d. 2017 dari ketiga pendekatan yang sedikit berbeda namun relatif beriringan sebagaimana diilustrasikan pada Gambar 3. Gambar tersebut juga menunjukkan bagaimana siklus bisnis Indonesia yang sempat naik di atas potensialnya di awal 1990-an hingga tahun 1997. Kemudian ekonomi Indonesia mengalami krisis menyebabkan kinerjanya terkontraksi cukup dalam hingga mencapai -13,1\% di tahun 1998 sehingga tumbuh jauh di bawah tingkat potensialnya. Selanjutnya, perekonomian Indonesia setelah periode krisis di awal tahun 2000-an hingga saat ini tumbuh relatif stabil yang terlihat dari tingkat pertumbuhan yang tidak terlalu jauh dari pertumbuhan potensialnya. Adapun hasil keseluruhan estimasi output potensial dan output gap dapat dilihat dalam Lampiran.

GAMBAR 3: Pertumbuhan Output Aktual dan Output Potensial 1994-2019 (\%, yoy) 


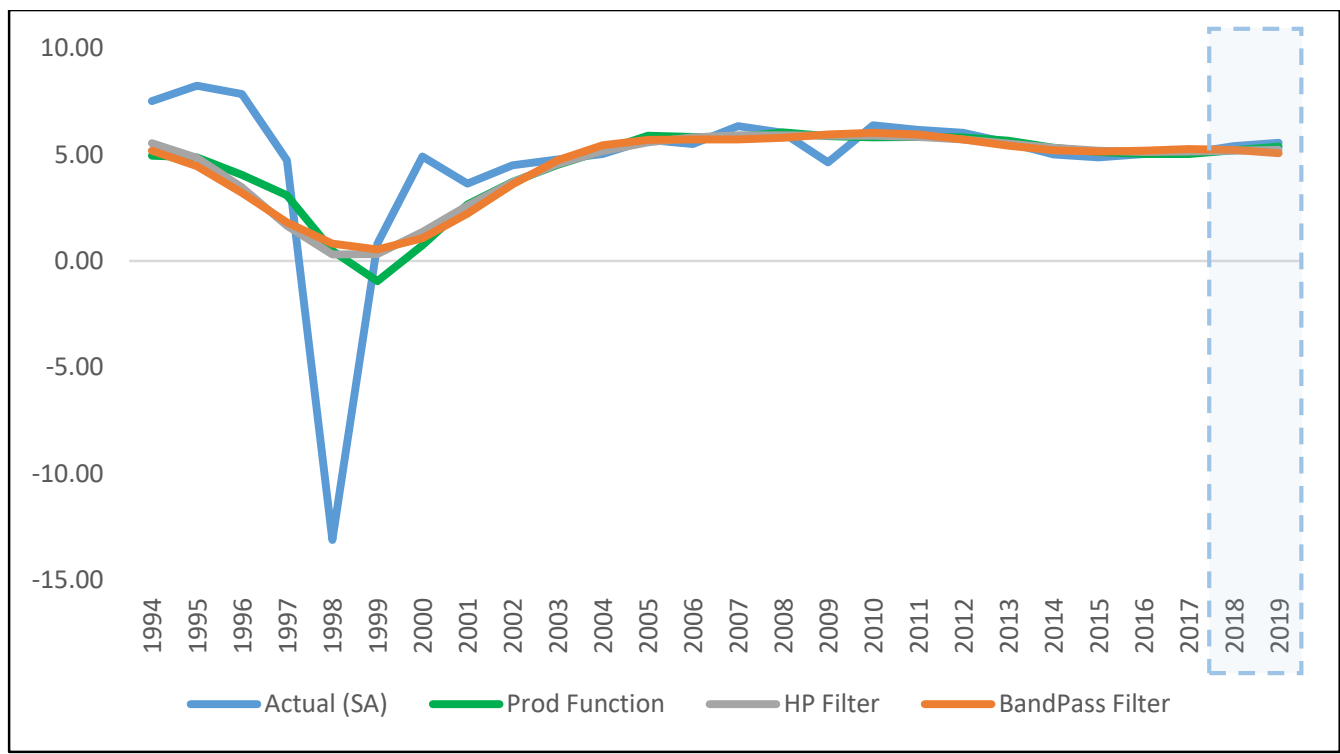

Sumber: BPS, Perhitungan Penulis. *)2018 dan 2019 angka estimasi.

Selanjutnya, Gambar 4 memberikan konfirmasi penjelasan yang sejalan dengan Gambar 3 namun dari sudut pandang besaran output gap pada periode 1994-2019. Berdasarkan Gambar 4 tersebut, terlihat bahwa output aktual Indonesia sebelum krisis keuangan Asia tahun 1998 berada jauh di atas output potensialnya. Aktivitas perekonomian yang ekspansif menyebabkan perekonomian nasional mengalami overheating akibat kondisi output gap yang positif cukup tinggi. Pada tahun 1998, terjadi krisis ekonomi yang melanda Indonesia dan sebagian besar negara di Asia lainnya sehingga mengakibatkan kondisi perekonomian mengalami resesi. Pada saat krisis, kinerja perekonomian menurun dan sebagian berhenti (sudden stop) yang menyebabkan tingginya tingkat pengangguran. Kondisi ini menyebabkan output aktual jauh di bawah output potensialnya tercermin ketiga metode estimasi output potensial yang konsisten menunjukkan output gap yang negatif cukup besar. Kondisi output gap negatif pascakrisis terus berlangsung sampai dengan tahun 2001 meskipun dengan tren yang semakin menyempit.

GAMBAR 4: Output Gap Tahun 1994-2019 (\%)

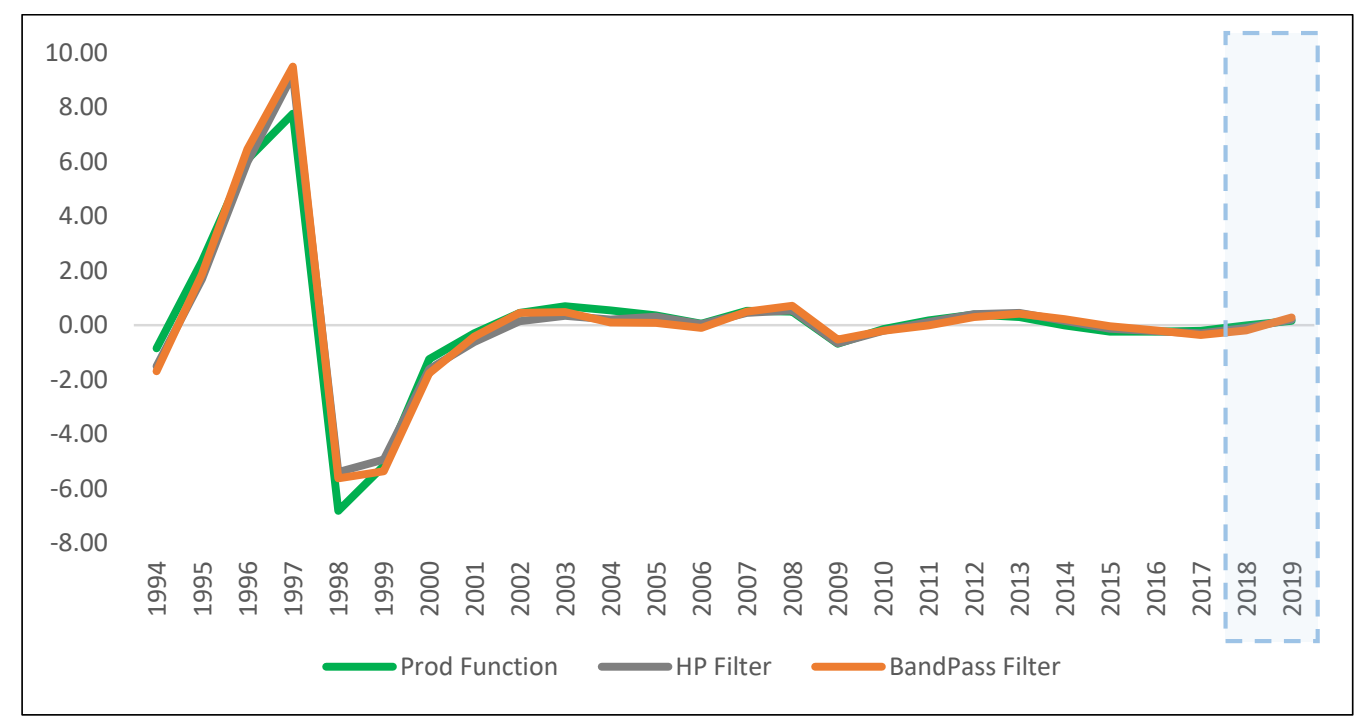

Sumber: Perhitungan Penulis. *)2018 dan 2019 angka estimasi.

Proses pemulihan ekonomi pascakrisis didorong oleh pertumbuhan konsumsi. Menurut Ikhsan (2005), peningkatan konsumsi tersebut didorong oleh konsumsi yang tertunda selama periode krisis, kenaikan upah minimun regional, transfer pemerintah melalui subsidi, dan ekspansi kredit konsumsi. Pada periode 2002-2008 perekonomian cenderung berada di atas level potensialnya dan menyebabkan output gap kembali bernilai positif. 
Pada akhir tahun 2008, terjadi krisis keuangan global yang diawali dengan terjadinya subprime mortgage yang mengakibatkan penutupan beberapa perusahaan besar di Amerika Serikat. Kondisi ini turut mempengaruhi kondisi perekonomian Indonesia yang tercermin dari tingkat pertumbuhan yang melambat dan menyebabkan output gap kembali pada level negatif ditahun 2009 dan 2010.

\section{GAMBAR 5: Output Gap Tahun 2011-2019 (\%)}

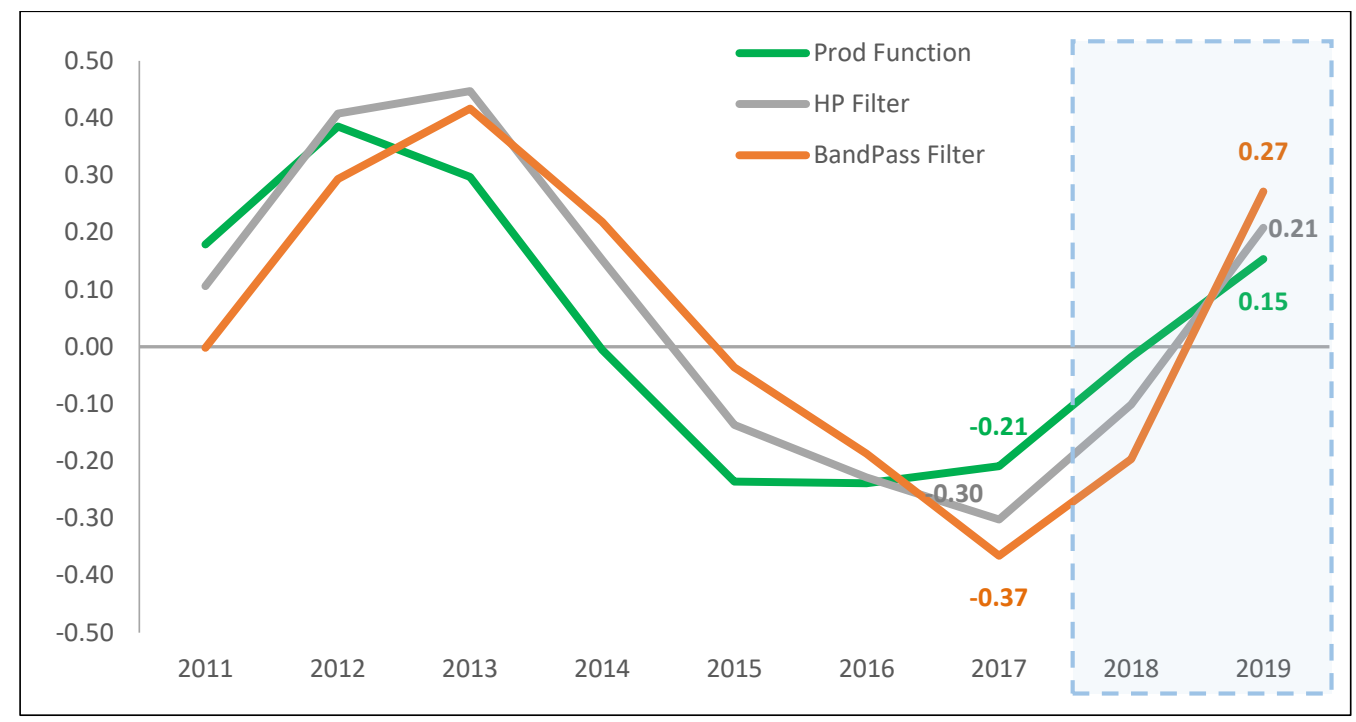

Sumber: Perhitungan Penulis. *)2018 dan 2019 angka estimasi.

Selanjutnya, Gambar 5 menunjukkan dinamika pasang surut perekonomian Indonesia sepanjang periode 2011-2019. Dalam periode tersebut, terlihat bahwa perekonomian Indonesia sempat mengalami output gap positif pada 2011-2014 kemudian kembali negatif pada 2015 hingga saat ini.

Pada periode 2011-2014, kondisi output gap yang positif terutama didorong oleh peningkatan kondisi peningkatan permintaan yang besar atas komoditas secara global (boom komoditas). Sebagai negara penghasil dan eksportir komoditas mentah seperti batu bara, CPO, dan mineral logam, hal ini berdampak pada kinerja perekonomian Indonesia yang tumbuh cukup tinggi. Secara umum pada masa tersebut, tingginya permintaan global yang diikuti kenaikan harga memberikan tambahan peningkatan pendapatan masyarakat yang pada gilirannya mendorong tingginya permintaan barang dan jasa. Kondisi tersebut selanjutnya diikuti dengan peningkatan inflasi karena terbatasnya potensi perekonomian.

Selanjutnya, pada periode 2015-2017, kondisi perekonomian global mengalami pelemahan yang tercermin dari kondisi perlambatan pertumbuhan ekonomi negara-negara maju dan berkembang, serta penurunan tajam sebagian besar harga komoditas global. Kondisi tersebut juga memberikan pengaruh terhadap perekonomian Indonesia yang tumbuh melambat. Hal ini selanjutnya menyebabkan output aktual Indonesia kembali berada di bawah level potensialnya (output gap negatif). Di tahun 2017, output gap masing-masing pendekatan adalah sebesar -0,30 (HP Filter), -0,37 (BP Filter) dan -0,21 (Fungsi Produksi).

Lebih jauh, dengan mengaplikasikan target kinerja pertumbuhan tahun 2018 dan 2019 masing-masing sebesar 5,4 persen dan 5,6 persen maka diperkirakan perekonomian Indonesia di tahun 2019 akan melampaui level potensialnya (output gap positif $0,15-0,27$ ). Hasil analisis tersebut juga mengindikasikan bahwa level pertumbuhan potensial Indonesia berada di kisaran 5,3 - 5,5 persen baik di tahun 2018 maupun 2019. Artinya ruang peningkatan perekonomian Indonesia untuk mencapai tingkat potensial saat ini sudah tidak terlalu lebar. Bahkan terdapat potensi kinerja perekonomian melebihi kapasitas optimal dan berisiko overheating.

Kondisi tersebut perlu menjadi perhatian dalam proses pengambilan kebijakan, baik dalam jangka pendek maupun menengah. Dalam jangka pendek, berdasarkan model kurva Phillip, output gap yang positif mendorong terjadinya tekanan inflasi (inflationary pressure). Oleh sebab itu, upaya pengendalian inflasi perlu dilakukan melalui bauran kebijakan fiskal yang countercyclical dan kebijakan moneter yang mampu meredam tekanan peningkatan ekspektasi inflasi, baik melalui pengendalian jumlah uang beredar maupun penetapan suku bunga acuan. 
Sementara itu, dalam jangka menengah, upaya peningkatan output potensial melalui peningkatan kapasitas produksi baik dari sisi tenaga kerja, investasi dan produktivitas mutlak diperlukan. Dalam rangka menganalisis upaya peningkatan kapasitas produksi tersebut, dilakukan dekomposisi terhadap hasil estimasi output potensial dan output gap dengan pendekatan fungsi produksi sebagaimana dijelaskan dalam bagian berikutnya.

\subsection{Evaluasi Metode Estimasi Output Potensial}

Dalam mengevaluasi metode estimasi output potensial, digunakan pendekatan model kurva Phillips yang membandingkan output gap dengan dinamika laju inflasi. Berdasarkan pendekatan kurva Phillips, pemilihan model terbaik didasarkan pada kemampuan output gap dalam menjelasakan dinamika inflasi. Dalam hal ini model yang baik seharusnya dapat menjelaskan pergerakan laju inflasi antar waktu (Nasution dan Hendranata, 2014). Adapun model kurva Phillips dapat dituliskan sebagai berikut:

$$
\pi_{t}=\alpha+\sum_{j-1}^{4} \beta_{t} \pi_{t-j}+\sum_{j-0}^{4} \beta \lambda_{j} \operatorname{ygap}_{t-j}+\varepsilon_{t}
$$

Dimana $\pi$ adalah laju inflasi dan ygap adalah output gap.

Tabel 2 menunjukkan hasil regresi masing-masing metode yaitu HP Filter, Band-Pass Filter, dan fungsi produksi dengan laju inflasi.

TABEL-2: Hasil Regresi Model Kurva Phillips

\begin{tabular}{|c|c|c|c|c|c|c|c|c|c|}
\hline \multirow{2}{*}{ Variabel } & \multicolumn{3}{|c|}{ HP Filter } & \multicolumn{3}{|c|}{ Band-Pass Filter } & \multicolumn{3}{|c|}{ Production Function } \\
\hline & Coef & $\mathrm{t}$-Stat & Prob & Coef & $\mathrm{t}$-Stat & Prob & Coef & $\mathrm{t}$-Stat & Prob \\
\hline C & 1.475 & 3.008 & $0.004^{*}$ & 1.445 & 2.907 & $0.005^{*}$ & 1.413 & 2.856 & $0.005^{*}$ \\
\hline ygap & -0.899 & -3.921 & $0.000^{*}$ & -0.882 & -3.864 & $0.000^{*}$ & -0.992 & -4.068 & $0.000 *$ \\
\hline $\operatorname{ygap}(-1)$ & 0.133 & 0.369 & 0.713 & 0.135 & 0.369 & 0.713 & 0.099 & 0.266 & 0.791 \\
\hline $\operatorname{ygap}(-2)$ & 0.124 & 0.450 & 0.654 & 0.120 & 0.428 & 0.670 & 0.129 & 0.444 & 0.658 \\
\hline $\operatorname{ygap}(-3)$ & 1.439 & 2.993 & $0.004^{*}$ & 1.436 & 2.945 & $0.004^{*}$ & 1.422 & 2.913 & $0.005^{*}$ \\
\hline $\operatorname{ygap}(-4)$ & -0.433 & -1.233 & 0.221 & -0.506 & -1.491 & 0.140 & -0.378 & -1.022 & 0.310 \\
\hline$\pi(-1)$ & 1.273 & 9.436 & $0.000^{*}$ & 1.297 & 9.913 & $0.000^{*}$ & 1.268 & 9.129 & $0.000^{*}$ \\
\hline$\pi(-2)$ & -0.362 & -2.527 & $0.013^{* *}$ & -0.383 & -2.707 & $0.008^{*}$ & -0.357 & -2.412 & $0.018^{* *}$ \\
\hline$\pi(-3)$ & -0.255 & -2.942 & $0.004^{*}$ & -0.256 & -2.914 & $0.005^{*}$ & -0.250 & -2.899 & $0.005^{*}$ \\
\hline$\pi(-4)$ & 0.187 & 3.534 & $0.001^{*}$ & 0.189 & 3.523 & $0.001^{*}$ & 0.190 & 3.545 & $0.001^{*}$ \\
\hline $\mathrm{R}^{2}$ & 0.962 & & & 0.961 & & & 0.962 & & \\
\hline $\operatorname{Adj} R^{2}$ & 0.958 & & & 0.957 & & & 0.958 & & \\
\hline F-statistic & 237.646 & & & 232.806 & & & 234.518 & & \\
\hline Prob(F-stat) & $0.000^{*}$ & & & $0.000^{*}$ & & & $0.000^{*}$ & & \\
\hline DW stat & 2.230 & & & 2.240 & & & 2.227 & & \\
\hline
\end{tabular}

Sumber: Perhitungan Penulis.

Keterangan ${ }^{*}$ ) signifikan pada $\alpha=1 \% ;{ }^{*}$ ) signifikan pada $\alpha=5 \%$.

Berdasarkan hasil regresi model Kurva Phillips dimaksud, ketiga metode menghasilkan nilai R-squared dan uji signifikansi (baik t maupun f) yang relatif sama dalam menjelaskan dinamika laju inflasi. Hal ini menunjukkan bahwa ketiga metode tersebut sama-sama menjadi model yang baik dalam mengestimasi output potensial. Namun demikian, metode fungsi produksi memiliki keunggulan dalam menjelaskan komponen pendorong pertumbuhan. Selanjutnya, metode fungsi produksi digunakan untuk menganalisis dampak faktor tenaga kerja, kapital, dan produktivitas terhadap kinerja perekonomian, baik di masa lalu maupun tren di masa yang akan datang. 


\subsection{Analisis Dekomposisi Pendekatan Fungsi Produksi}

Sebagaimana dijelaskan sebelumnya, pendekatan fungsi produksi merupakan pendekatan quasi-theoritical yang didasarkan pada model pertumbuhan Solow yang menghubungkan pertumbuhan dengan variabel faktor pendorong pertumbuhan seperti tenaga kerja, kapital, dan produktivitas (Total Factor Productivity). Hal ini memungkinkan dilakukannya estimasi atas dekomposisi faktor pendorong pertumbuhan ekonomi dari periode 1994 sampai dengan 2017 baik untuk kontributor output aktual maupun output potensial sebagaimana ditunjukkan oleh Tabel 3 dan Tabel 4.

Berdasarkan data dalam Tabel 3, kinerja perekonomian Indonesia didominasi peran kapital dengan kontribusi sebesar 50,0 persen (2,3 dari 4,6 persen pertumbuhan ekonomi), kemudian disusul oleh TFP sebesar 29,7 persen (1,4 dari 4,6 persen) dan tenaga kerja 20,0 persen (0,9 dari 4,6 persen). Peran kapital yang cukup besar tersebut sejalan dengan kontribusi investasi terhadap PDB yang terus menunjukkan tren peningkatan sejak periode krisis. Sementara itu, kontribusi tenaga kerja relatif mengalami penurunan.

TABEL-3: Kontribusi Komponen Faktor Produksi terhadap Total Output Aktual

\begin{tabular}{|c|c|c|c|c|c|c|c|c|}
\hline Period & $\begin{array}{l}1994- \\
1997 \\
\end{array}$ & $\begin{array}{c}1998- \\
1999\end{array}$ & $\begin{array}{l}2000- \\
2003\end{array}$ & $\begin{array}{l}2004- \\
2007\end{array}$ & $\begin{array}{c}2008- \\
2010\end{array}$ & $\begin{array}{l}2011- \\
2014\end{array}$ & $\begin{array}{l}2015- \\
2017\end{array}$ & $\begin{array}{l}1994- \\
2017\end{array}$ \\
\hline Average Growth (\%) & 7.1 & -6.1 & 4.5 & 5.6 & 5.7 & 5.7 & 5.0 & 4.6 \\
\hline TFP (\%) & 2.3 & -7.7 & 3.0 & 2.8 & 1.7 & 1.9 & 1.2 & 1.4 \\
\hline Capital (\%) & 3.6 & 0.5 & 0.9 & 1.9 & 2.7 & 3.1 & 2.9 & 2.3 \\
\hline Labor (\%) & 1.3 & 1.1 & 0.5 & 0.9 & 1.3 & 0.7 & 0.9 & 0.9 \\
\hline \multicolumn{9}{|l|}{ Memo items: } \\
\hline Gross Investment Rate (\%) & 34.9 & 26.1 & 26.0 & 28.6 & 30.7 & 32.4 & 32.4 & 30.4 \\
\hline
\end{tabular}

Sumber: BPS, Perhitungan Penulis.

Lebih lanjut, hasil dekomposisi output potensial yang diperlihatkan dalam Tabel 4 secara umum menunjukkan kondisi yang mirip dengan hasil dekomposisi output aktual dalam periode 1994 s.d. 2017. Jika ditinjau lebih detail pada periode analisis 2015-2017, output aktual berada di bawah output potensial. Kondisi ini terutama disebabkan oleh kontribusi TFP dan kapital yang masih berada di bawah level potensialnya, sementara kontribusi dari tenaga kerja sudah sedikit lebih tinggi dibandingkan dengan potensialnya.

TABEL-4 Kontribusi Komponen Faktor Produksi terhadap Total Output Potensial

\begin{tabular}{lcccccccc}
\hline \multicolumn{1}{c}{ Period } & $1994-$ & $1998-$ & $2000-$ & $2004-$ & $2008-$ & $2011-$ & $2015-$ & $1994-$ \\
& 1997 & 1999 & 2003 & 2007 & 2010 & 2014 & 2017 & 2017 \\
\hline & & & & & & & & \\
Average Growth (\%) & 4.2 & -0.2 & 2.9 & 5.7 & 5.9 & 5.7 & 5.1 & 4.4 \\
TFP (\%) & -0.5 & -1.6 & 1.4 & 2.9 & 1.9 & 1.6 & 1.3 & 1.2 \\
Capital (\%) & 3.6 & 0.5 & 0.9 & 1.9 & 2.7 & 3.1 & 2.9 & 2.3 \\
Labor (\%) & 1.2 & 0.9 & 0.6 & 0.9 & 1.3 & 1.0 & 0.8 & 0.9 \\
\hline
\end{tabular}

Sumber: Perhitungan Penulis.

Sebagaimana dijelaskan sebelumnya bahwa hasil diagnosis pertumbuhan ekonomi dan output potensial menunjukkan bahwa ruang peningkatan dan optimalisasi potensi perekonomian semakin terbatas. Hal ini mengindikasikan perlunya upaya-upaya untuk meningkatkan kapasitas ekonomi yang pada gilirannya meningkatkan output potensial. Upaya tersebut dilakukan dengan meningkakan kontribusi sisi supply, dalam hal ini mencakup aspek tenaga kerja, modal, dan produktivitas yang juga merupakan komponen dalam pendekatan fungsi produksi. 
GAMBAR 6: Rata-Rata Pertumbuhan Output Aktual dan Potensial Berdasarkan Komponen Faktor Produksi (\%)

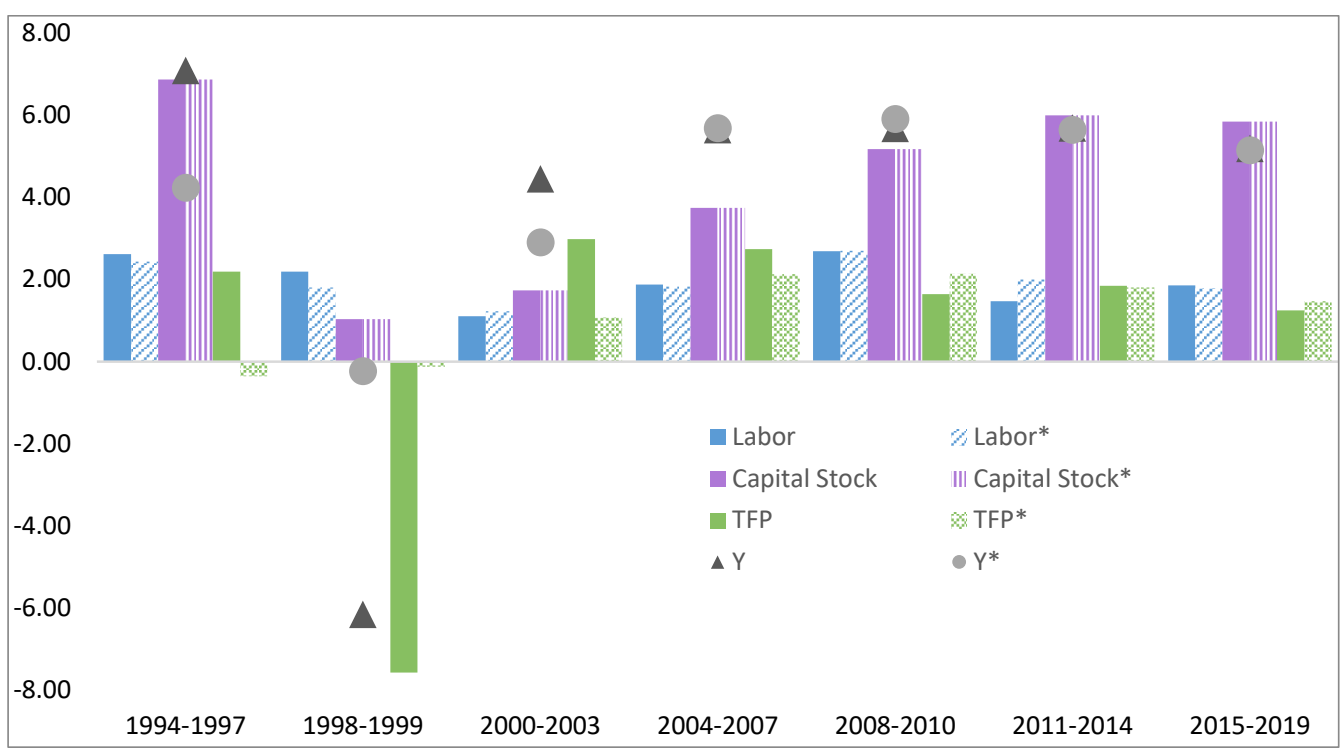

Sumber: Perhitungan Penulis.

Berdasarkan ilustrasi pada Gambar 6, sumber pertumbuhan ekonomi Indonesia sebagian besar didorong oleh peningkatan akumulasi modal. Sementara itu kontribusi dari komponen tenaga kerja dan komponen TFP cenderung menurun dalam beberapa tahun terakhir. Hal ini mencerminkan kondisi peningkatan penguasaan teknologi dan produktivitas yang masih relatif rendah. Menurut Anand et al (2014), kondisi rendahnya kontribusi TFP disebabkan oleh beberapa faktor, antara lain: rendahnya tingkat penelitian dan pengembangan (research and development), infrastruktur yang belum memadai, rendahya tingkat complexity economy khususnya pada sektor industri pengolahan, serta prosedur perizinan yang relatif kompleks dalam proses memulai bisnis.

Hal ini menjadi petunjuk awal bagaimana fokus reformasi struktural guna mengoptimalkan sumber-sumber pertumbuhan ekonomi nasional. Arah kebijakan pemerintah yang dapat mendukung reformasi struktural dapat dilakukan melalui kombinasi kebijakan untuk meningkatkan faktor tenaga kerja, investasi, dan produktivitas.

\section{KESIMPULAN DAN REKOMENDASI}

Hasil estimasi output potensial dan output gap Indonesia berdasarkan pendekatan HP Filter, BP Filter, dan Fungsi Produksi secara konsisten menunjukkan bahwa kondisi perekonomian Indonesia di tahun 2017 hanya sedikit di bawah level potensialnya. Artinya, ruang peningkatan perekonomian Indonesia untuk mencapai tingkat potensial saat ini sudah tidak terlalu lebar. Bahkan terdapat potensi perekonomian Indonesia melampaui level potensialnya jika asumsi kinerja pertumbuhan ekonomi 2018 dan 2019 mampu dicapai. Kondisi tersebut dapat menjadi bahan masukan dalam upaya perbaikan fundamental perekonomian nasional, baik dalam jangka pendek maupun menengah.

Dalam jangka pendek, langkah kebijakan yang dilakukan adalah mengupayakan pengendalian inflasi melalui bauran kebijakan fiskal dan moneter yang mampu meredam tekanan inflasi. Dalam jangka menengah dan panjang, implementasi langkah kebijakan mendorong reformasi struktural juga diperlukan untuk mendorong kontribusi faktor produksi, baik dari sisi tenaga kerja, kapital, serta produktivitas.

Dari sisi tenaga kerja, pertumbuhan jumlah tenaga kerja cenderung terus mengalami perlambatan. Meski demikian, potensi tenaga kerja masih dapat ditingkatkan antara lain melalui:

1) Peningkatan tingkat partisipasi angkatan kerja (TPAK) yang pada Agustus 2017 masih sekitar 66,67 persen dengan rincian TPAK laki-laki sebesar 82,5l persen, sementara TPAK perempuan sebesar 50,89 persen. Jika dianalisis lebih lanjut, TPAK perempuan di Indonesia secara persisten berada di level yang relatif rendah dan memiliki gap lebih dari 30 persen dibandingkan dengan TPAK laki-laki. Padahal rata-rata gender gap dunia adalah sekitar 27 persen (AIPEG, 2017). Terdapat ruang yang cukup besar untuk meningkatkan TPAK, 
terutama peningkatan partisipasi angkatan kerja perempuan untuk dapat memberikan dampak positif terhadap perekonomian nasional.

2) Upaya peningkatan partisipasi TPAK tentu harus dibarengi dengan upaya penciptaan lapangan pekerjaan dengan produktivitas tinggi yang sejalan dengan langkah mendorong investasi kapital.

3) Peningkatan kualitas sumber daya manusia (human capital) melalui pendidikan dan keterampilan, termasuk menyesuaikan kurikulum pendidikan sekolah umum dan vokasional guna dapat link and match dengan kebutuhan pasar tenaga kerja.

Dari sisi kapital, upaya peningkatan potensialnya langsung tercermin dari peningkatan akselerasi pertumbuhan investasi. Upaya mendorong investasi secara umum dapat dilakukan melalui tiga cara, yakni:

1) Mendorong kemudahan investasi yang mencakup penyederhanaan dan prosedur perizinan dan birokrasi, mengurangi inefisiensi dan ekonomi biaya tinggi serta melakukan deregulasi aturan-aturan yang tidak market friendly.

2) Menyediakan infrastruktur dasar dan sarana pendukung bagi pelaku industri. Upaya perencanaan dan penyediaan infrastruktur pendukung perlu terus menjadi prioritas pemerintah karena sulitnya mengharapkan peranan swasta.

3) Mendorong peningkatan penanaman modal asing, terutama yang berorientasi ekspor. Sehingga tingginya beban terhadap neraca transaksi berjalan dari penanaman modal tersebut dapat terkompensasi dengan penambahan kapasitas ekspor.

Sementara itu, upaya peningkatan produktivitas juga menjadi kunci dalam mendorong pertumbuhan ekonomi nasional yang berkelanjutan baik melalui peningkatan penguasaan teknologi, dan efisiensi produksi. Hal ini pada dasarnya sejalan dengan peningkatan efisiensi pasar tenaga kerja dan investasi kapital. Tingkat produktivitas diyakini akan meningkat seiring dengan peningkatan kualitas sumber daya manusia dan peningkatan akumulasi modal.

\section{UCAPAN TERIMA KASIH}

Ucapan terima kasih kami sampaikan kepada Kepala Pusat Kebijakan Ekonomi Makro, Badan Kebijakan Fiskal, Kementerian Keuangan yang telah memberikan dukungan dan kesempatan kepada penulis untuk berdiskusi dalam penyelesaian substansi penelitian ini.

\section{DAFTAR PUSTAKA}

AIPEG. (22 Agustus 2017). Growth Accounting Variation: Economic Gains From Boosting Women's Labor Force Participation in Indonesia. disampaikan pada Workshop Potential Output di Jakarta.

Anand, R., Cheng, K., Rehman, S., \& Zhang, L. (2014). Potential Growth in Emerging Asia. IMF Working Paper WP/14/2, 1-25.

Badan Pusat Statistik. (2017, Desember 14). Retrieved from https://www.bps.go.id/statictable/2009/04/16/970/penduduk-15-tahun-ke-atas-yang-bekerjamenurut-lapangan-pekerjaan-utama-1986---2017.html

CEIC. (2017, Desember 14). Indonesia Premium Database: National Account Data. Retrieved from https://cas.ceicdata.com/login

Christiano,f L., \& Fitzgerald, T. (1999). The Band Pass Filter. NBER Working Paper Series, Cambridge.

De Masi, P. (1997). IMF Estimates of Potential Output: Theory and Practice. IMF Working Paper WP/97/177, 1-14.

Feenstra, R., Inklaar, R., \& Timmer, M. (2015). The Next Generation of the Penn World Table. American Economic Review, 105(10), 3150-3182, available for download at www.ggdc.net/pwt.

Ikhsan, M. (2005). Skenario Pertumbuhan Ekonomi Jangka Menengah 2005-2009. LPEM Working Paper No. 9/2005, $1-20$.

Khatri, Yougesh AIPEG. (22 August 2017). Estimating Indonesia's Potential Output: Options and Common Approaches. disampaikan pada Workshop Potential Output di Jakarta. 
Mankiw, N. Gregory. (2010). Macroeconomics Seventh Edition. New York: Worth Publishers.

Mitra, P., Hosny, A., Abajyan, H., \& Fischer, M. (2015). Estimating Potential Growth in the Middle East and Central Asia. IMF Working Paper WP/15/62, 1-25.

Nasution, D., \& Hendranata, A. (2014). Estimasi Output Gap Indonesia. Pusat Kebijakan Ekonomi Makro, Badan Kebijakan Fiskal, Kementerian Keuangan.

Rinaldi, Rullan; Saputro, Adhi N.; AIPEG. (22 August 2017). Simple Growth Accounting Framework for Deriving Potential Growth in Indonesia. disampaikan pada Workshop Potential Output di Jakarta.

Sigit, H. (2004). Total Factor Productivity Growth: Survey Report. Tokyo: Asian Productivity Organization.

Tjahjono, E. D., Munandar, H., \& Waluyo, J. (2010). Revisiting Estimasi Potential Output dan Output Gap Indonesia: Pendekatan Fungsi Produksi Berbasis Model. Working Paper Bank Indonesia WP/02/2010, 1-43.

Todaro, M., \& Smith, S. (2006). Economic Development Ninth Edition. Boston: Pearson Addison Wesley.

Van der Eng, P. (2009). Total Factor Productivity and Economic Growth in Indonesia. Working Papers in Trade and Development No 2009/01, ANU, 1-30. 
LAMPIRAN: Hasil Estimasi Output Potensial dan Output Gap

\begin{tabular}{|c|c|c|c|c|c|c|c|c|}
\hline \multirow[t]{2}{*}{ Tahun } & \multicolumn{2}{|c|}{ Output Aktual (Rp. triliun) } & \multicolumn{3}{|c|}{ Output Potensial (Rp. triliun) } & \multicolumn{3}{|c|}{ Output Gap (persen) } \\
\hline & $\begin{array}{c}\text { Non Seasonal } \\
\text { Adjusted (NSA) }\end{array}$ & $\begin{array}{c}\text { Seasonal Adjusted } \\
\text { (SA) }\end{array}$ & HP Filter & BandPass Filter & $\begin{array}{l}\text { Production } \\
\text { Function }\end{array}$ & HP Filter & BandPass Filter & $\begin{array}{l}\text { Production } \\
\text { Function }\end{array}$ \\
\hline 1993 & $3,377.09$ & $3,406.55$ & $3,523.84$ & $3,541.80$ & $3,520.29$ & -3.33 & -3.82 & -3.23 \\
\hline 1994 & $3,631.72$ & $3,662.91$ & $3,719.13$ & $3,725.80$ & $3,694.34$ & -1.51 & -1.69 & -0.85 \\
\hline 1995 & $3,930.25$ & $3,965.02$ & $3,899.36$ & $3,891.91$ & $3,874.13$ & 1.68 & 1.88 & 2.35 \\
\hline 1996 & $4,237.53$ & $4,276.04$ & $4,034.26$ & $4,016.69$ & $4,031.11$ & 5.99 & 6.46 & 6.08 \\
\hline 1997 & $4,436.68$ & $4,478.49$ & $4,100.97$ & $4,089.96$ & $4,155.84$ & 9.21 & 9.50 & 7.76 \\
\hline 1998 & $3,854.29$ & $3,891.47$ & $4,113.47$ & $4,123.41$ & $4,176.33$ & -5.40 & -5.62 & -6.82 \\
\hline 1999 & $3,884.78$ & $3,923.06$ & $4,127.06$ & $4,145.53$ & $4,136.94$ & -4.94 & -5.37 & -5.17 \\
\hline 2000 & $4,078.19$ & $4,115.59$ & $4,183.22$ & $4,189.88$ & $4,167.51$ & -1.62 & -1.77 & -1.25 \\
\hline 2001 & $4,226.78$ & $4,265.33$ & $4,292.17$ & $4,283.15$ & $4,278.36$ & -0.63 & -0.42 & -0.30 \\
\hline 2002 & $4,416.96$ & $4,457.10$ & $4,451.04$ & $4,436.98$ & $4,437.35$ & 0.14 & 0.45 & 0.45 \\
\hline 2003 & $4,628.11$ & $4,669.71$ & $4,653.75$ & $4,647.27$ & $4,637.63$ & 0.34 & 0.48 & 0.69 \\
\hline 2004 & $4,860.95$ & $4,904.53$ & $4,894.18$ & 4,899.99 & $4,877.99$ & 0.21 & 0.09 & 0.54 \\
\hline 2005 & $5,137.66$ & $5,183.41$ & $5,166.96$ & $5,179.17$ & $5,165.21$ & 0.32 & 0.08 & 0.35 \\
\hline 2006 & $5,420.28$ & $5,468.88$ & $5,467.09$ & $5,474.86$ & $5,466.26$ & 0.03 & -0.11 & 0.05 \\
\hline 2007 & $5,764.20$ & $5,816.15$ & $5,790.44$ & $5,787.20$ & $5,785.35$ & 0.44 & 0.50 & 0.53 \\
\hline 2008 & $6,110.84$ & $6,166.33$ & $6,133.17$ & $6,122.72$ & $6,135.50$ & 0.54 & 0.71 & 0.50 \\
\hline 2009 & $6,393.70$ & $6,451.73$ & $6,494.75$ & $6,486.60$ & $6,496.14$ & -0.66 & -0.54 & -0.68 \\
\hline 2010 & $6,864.13$ & $6,863.31$ & $6,877.34$ & $6,877.56$ & $6,873.20$ & -0.20 & -0.21 & -0.14 \\
\hline 2011 & $7,287.64$ & $7,286.74$ & $7,279.06$ & $7,286.92$ & $7,273.74$ & 0.11 & 0.00 & 0.18 \\
\hline 2012 & $7,727.08$ & $7,725.87$ & $7,694.51$ & $7,703.31$ & $7,696.23$ & 0.41 & 0.29 & 0.39 \\
\hline 2013 & $8,156.50$ & $8,154.93$ & $8,118.64$ & $8,121.10$ & $8,130.78$ & 0.45 & 0.42 & 0.30 \\
\hline 2014 & $8,564.87$ & $8,563.14$ & $8,550.22$ & $8,544.52$ & $8,563.68$ & 0.15 & 0.22 & -0.01 \\
\hline 2015 & $8,982.52$ & $8,980.76$ & $8,993.17$ & $8,984.13$ & $9,002.10$ & -0.14 & -0.04 & -0.24 \\
\hline 2016 & $9,434.63$ & $9,432.79$ & $9,454.52$ & $9,450.54$ & $9,455.48$ & -0.23 & -0.19 & -0.24 \\
\hline 2017 & $9,912.75$ & $9,911.00$ & $9,941.11$ & $9,947.47$ & $9,931.88$ & -0.30 & -0.37 & -0.21 \\
\hline
\end{tabular}

Sumber: BPS, Perhitungan Penulis. 